\title{
A REVIEW OF EXPERIMENTAL TECHNIQUES RELATED TO ANTHROPOMETRIC ASSESSMENT
}

\author{
${ }^{*}$ D. A. BRODIE, B.Ed., M.Sc., M.I.Biol. \\ †J. GOLBY and R. W. PHILLIPS \\ School of Physical Education, City of Leeds and Carnegi College
}

\section{Introduction}

This paper presents a review of the methods available to established body composition. The study of body composition is described by Karpovitch and Sinning (1971) as the study of the existing composition or the changes in composition within the frame. This can be approached in many ways. Passmore and Robson (1971) use a simple but valuable method of splitting the body into three components for ease of analysis. The first division is into the cell mass, where most of the chemical work of the body is done. Second is the supporting tissue, which includes the extracellular fluids in the blood and the fluids surrounding the cells in the various organs. Third is the energy reserve, which is composed mainly of fat held for the most part in the adipose tissue. If this method of division of the body is used, and then various modern methods of assessment of these components is considered, it is found that the techniques are in many ways similar.

These methods can then be categorised into four main groups: external linear measurement, density measurement, chemical processes and instrumental techniques. It is clear that all these methods are indirect since, for obvious reasons, biopsy is rarely practical.

* Research Fellow

t Dip. Phys. Education students

\section{External Linear Measurement}

Assessment of body composition by external linear measurement is one area of analysis that has been available for a long time. The original method was based on the age/height/weight tables. Although there exists a relationship between fat and body-weight (Keys and Brozek, 1953), this was not a reliable prediction of exact body composition.

Before the war Sheldon (1940) did much work in this field, as too did Parnell (1958). The measurement of various areas of the body to give readings for fatness, muscularity and linearity by taking readings for height, weight, skinfold, bone width and muscle circumferences, and then plotting these readings to give ratings are well known. Heath (1963) outlines certain modifications of these methods. Wilmore, Girandola and Moody (1971) showed that skinfold tests are subject to quite large errors. Brozek, et. al. (1963), however, defends this method and claims "it serves as a useful indicator of fatness of individuals and groups of individuals", but points out in partnership with Keys (1953), that the method has its faults. These techniques of linear measurement or anthropometric techniques are very quick, cheap and easy to perform, but they lack the accuracy of the three other kinds of assessment.

Sheldon's "Atlas of Man" (1954) was produced to make available a standard file of somatotype variations, together with the criteria actually employed in somatotyping, so that correlative enquiry could be carried out. His earlier work (1940) suggested a method which became widely accepted although the delay in producing the Atlas caused some criticism at the time. There is no question, however, that numerous studies in sports and medicine have since been completed in which Sheldon's methods have been used successfully.

Heath and Carter (1966), proposed an extended scale outside the confines of the 1.7 continuum that Sheldon adopted for each component. This modification was found to be highly satisfactory for the 1st component (endomorphy) and the 3rd component (ectomorphy) and satisfactory for mesomorphy. It disregards the age correction factor as Heath and Carter disagree with the predictive aspect of the Sheldonian system.

The advantages of this method are that the subject is not inconvenienced, and all classes of subjects can be measured: there is no need for the maintenance of large equipment; measurements can be made at leisure and additional measurements can be made at a later stage without regard to the physical well-being of the subject. On the other hand, it would require intensive training to make accurate observations from a photograph and it is questionable whether it is possible to make estimates of a three dimensional nature from a two dimensional photograph. It is for these types of reasons that Parnell (1958) developed anthropometric techniques for measuring bone and muscle. There is a vast array of research which demonstrate the relationship of skeletal diameters and skinfold measures to lean body weight, (Wilmore and Behnke, 1969, Behnke, 1963, Van Dobelin, 1961, and Falkner 1963). Any disagreement about this method seems to be related to exactly how many skeletal and skinfold measurements need to be taken and where the siting of such measurements should 
be (Brozek and Keys, 1950 and 1952, Sloan, Burt and Blythe, 1962). Falkner (1963) provides an argument against skeletal and skinfold measurements. He questions whether relatively simple anthropometric methods can yield reliable information on body composition. He states that sub-cutaneous fat is difficult to measure, bone composition and density change considerably with ageing and that skeletal muscle can be altered.

The methods stated above may be inappropriate for many students of body composition because the specialised equipment is not available. However sliding anthropometers could be manufactured in the workshops of most educational institutions. These could be in the form of projections which slide on a steel or aluminium bar and would be clamped tight at the appropriate bone diameter. The distance between the projections could then be measured with a metre rule. Providing the projections are designed to be at exact right angles to the bar, these results can provide very useful measures of bone dimensions.

The unavailability of skinfold calipers presents more of a problem in terms of manufacturing an alternative, but there are available very inexpensive models which may be satisfactory for student or school use. The Ponderax Mark IV skinfold caliper is such an example (Servier Laboratories Ltd.,) which although it does not conform to recommended specifications, (Tanner and Whitehouse, 1955) it does give a skinfold reading in $\mathrm{mm}$.

If the photographic method is adopted by a student of body composition, the process involving Dia Direct film (Agva-Gevaert Ltd.,) is recommended. This film produces a transparency directly from the film without the intermediate stage of a negative. The film is processed by the manufacturer and usually returned within a few days of posting. This means that photographs taken as part of a series of weekly lectures can be presented at the next lecture. The transparencies can be projected to full size by careful comparison with a standard metre length included in the photograph and external linear measurements taken from the photograph.

\section{Density measurement}

These methods have been found to be extremely accurate (Brozek, et. al., 1963). However, there are several variables that could affect true readings e.g. temperature of water and volume of air in lungs at time of weighing, which would act as a built in flotation device that reduces the weight of the body in water. Many people are also very apprehensive about complete body

\footnotetext{
A. W. Sloan found that the inexpensive plastic calliper supplied by Servier Laboratories - the "Ponderax" model, gave a reasonably reliable fat-fold reading compared with the Harpenden calliper. Sufficient for most clinical purposes. His results were reported in a letter to the Brit. Med. Journ. during 1975 Editor.
}

immersion and this method could not be applied to young children or seriously ill children. The volume of the body can also be found by application of Boyle's Law. This states that if a body is placed in a closed chamber the gas space within the chamber will be reduced in proportion to the volume of the body. Falkner (1963) and Gaedinger et. al., (1963) have used this method to estimate volume. It would seem that this is an excellent method for the assessment of volume of inanimate objects but is not so simple when dealing with living organisms which are constantly generating heat and water vapour and respiring within their own environment. Helium displacement instead of air displacement would appear to be a more accurate method (Fomen, Jesen and Owens, 1963) as this relates more specifically to chemical changes that take place within the body.

A further densiometric method is that of the body plethysmograph. This is an airtight chamber large enough to contain a person and having a known volume. With the subject in the chamber, a measured amount of air is injected into the chamber and the resulting change in pressure is noted. The change in pressure is a function of the relationship between the two volumes, that of the air surrounding the subject in the chamber and that of the air injected.

Once again such methods have limited application because of the complexity of the apparatus. It is possible to make approximate measurements of $\operatorname{limb}$ and total body volumes by using large tanks, such as those used in a domestic cold water system and noting the volume of water displaced. Reasonable attempts have also been made by weighing subjects above and under water in a swimming pool. Such methods, although crude, may explain the theory involved in the procedure.

\section{Chemical processes}

The chemical methods of assessment of body composition are many and varied. Many of these seem to work on the dilution principle. This is a means of measuring various components of the body by the injection of a dye or foreign liquid into the area to be tested, and after the dye is allowed to diffuse a sample of the liquid is taken and the concentration of the dye is determined. By this method it is possible to work out the various components of the area under examination. A variety of substances are used in this work, e.g. deuterium oxide, tritiated water, anti-pyrine and amino antipyrine and ethyl alcohol. Gerson, Lesser and Zak (1963) used this principle working with gases. Cureton (1947) uses Soxhlet's technique in which fatty or lipid constituents can be extracted by repeated treatment with distilled solvents and thus assessed. Root and Allan (1960) have shown that some of these chemical methods are subject to slight error because of absorption of the chemicals or gases into various other parts of the body. 
They therefore used radio-active isotopes. Hansard (1963) outlines many of these methods, and claims that these methods are bringing increased reliability and great contributions to knowledge of body composition. In an area where even greater details of knowledge are required, such as the assessment of the total body potassium, various complex chemical methods are used. Miller and Remenchick (1968) show this clearly in their detailed studies on the subject.

\section{Instrumental techniques}

The final category of methods of assessment of body composition is the use of instrumental techniques. Many of the techniques already mentioned will have used, to some degree, instrumental methods. The ultra-sonic method has aroused much enthusiasm. This method is related to the fact that muscle, fat and connective tissue have different densities and accoustic properties, (Hazel and Kline, 1959, Stouffer, Wallentine and Wellington, 1959). Due to its ability to detect small tissue density differences, it would seem a most accurate and feasible method. A disadvantage would seem to be that it provides measurements at specific locations rather than an indication of total composition. There would seem a need for quantitative research to establish that examination at specific points of the body would give an accurate reflection of total composition.

$\mathrm{X}$-raying as a means of assessing body structure has been long established, particularly in relation to bones. Stouffer (1963) established a high correlation between this method and the ultrasonic method. It was noted, however, that it was difficult in some areas to measure the exact extent of the fat shadow. The main limitation would seem to be the danger of exposing humans to the radio-active material, but might be useful in a comparative analysis of tissue make-up in children and adults where there is a considerable cime lapse between $\mathrm{X}$-rays. Boling (1963) refers to a vise-configuration counter in his assessment of $\mathrm{K}^{42}, \mathrm{Na}^{24}, \mathrm{Br}^{82}$ and tritiated water concentration in man. Miller and Remenchick (1963) used a tilting chair technique in his assessment of body potassium. Pierson (1963) refers to a photo-grammetric technique of projecting, and thus measuring indirectly, the body contours by means of a camera, and this enables him to evaluate the composition.

It is hoped that anyone involved in the assessment of body composition will find this review of methods useful. With the many techniques and procedures available, the practitioner will often be forced into a compromise between selecting a technique which delineates the specific aspect of body composition that he wishes to study and the factors of expense, time, resources and man. power.

From the literature it is apparent that some standardization is required. Behnke (1963) in his analysis of much of the modern work on body composition states that these techniques are so varied that

"until we have a National Institute of Corporeal Standards for measurements on the analysis of the body as a whole and its component tissues and organs, we are left to applying our diversified methodology and ubiquitous ideas to acquiring data".

A major contribution to the process of standardization is the International Biological Programme handbook "Human Biology - a guide to field methods", Weiner and Lourie (1969). This text is based on contribution from over 100 human biologists and gives valuable information, among other things, on sources of equipment and computer proforma.

The present authors have had little experience with the diverse methods reviewed above, but have found that with careful training the anthropometric technique can yield highly reliable measures. For the researcher who has a primary interest in phenotyping it is felt that the experience in this technique does afford comparative information which is of considerable value to the sportsman, the physical educationist and the life scientist.

\section{REFERENCES}

Behnke, A. R. 1963, Anthropometric evaluation of body composition. Annals N.Y. Academy of Science, 110: 64.

Behnke, A. R. 1963, Conclusions of the Annals of the New York Academy of Sciences, Annals of N.Y. Academy of Science, 110: 1018.

Boling, E. A. 1963, Determination of $\mathrm{K}^{42}, \mathrm{Na}^{24}, \mathrm{Br}^{82}$ and tritiated water concentration in man. Annals of N.Y. Academy of Science, 110: 246.

Brozek, J., Grande, F., Anderson, T. and Keys, A. 1963, The determination of total body fat by means of the body specific gravity. Annals of N.Y. Academy of Science, 110: 131.

Brozek, J. and Keys, A. 1952, Body build and body composition, Science, 116: 140. 
Brozek, J. and Keys, A. 1950, Evaluation of leanness-fatness in man: a survey of methods Nutrition Abstracts and Reviews, 20: 247.

Brozek, J., Kihlberg, J. K., Taylor, H. L. and Keys, A. 1963, Skinfold distribution in middle aged American man. Annals N.Y. Academy of Science, 110: 492.

Cureton, T. K. 1947, Physical fitness appraisal and guidance, St. Louis, C. V. Mosby Co.

Falkner, F. 1963, Can simple anthropometric and radiographic methods yield reliable information on body composition? Annals N.Y. Academy of Science, 110: 1.

Falkner, F. 1963, An air displacement method of measuring body volume in babies. Annals of N.Y. Academy of Science, 110: 80 .

Fomen, S. J., Jesen, L. and Owens, G. M. 1963, Determination of the body volume of infants by the method of helium displacement. Annals of N.Y. Academy of Science, 110: 80.

Gaedinger, R. H., Reinke, E. P., Pearson, A. M., Van Hus, W. D., Wessel, H. J. and Montoye, H. J. 1963, Determination of body density by air displacement, Helium dilution and under-water weighing. Annals of N.Y. Academy of Science, 110: 96 .

Gerson, T., Lesser, A. and Zak, G. 1963, Measurement of total body fat in man by the simultaneous absorption of two inert gases. Annals of N.Y. Academy of Sciences, 110: 40.

Hansard, S. L. 1963, Radiochemical procedures for estimating body composition in animals. Annals of N. Y. Academy of Science, 110: 175.

Hazel, L. H. and Kline, E. A. 1959, Ultrasonic measurement of fatness in swine. J. Animal Science, 18: 815.

Heath, B. H. 1963, Need for modifications of somatotype methodology. Am.J.Physiol., 21: 313.

Heath, B. H. and Carter, J. E. L. 1966, A comparison of somatotype methods. Am.J.Phys.Anthrop. 24: 87.

Karpovitch, P. V. and Sinning, W. E. 1971, Physiology of muscular activity. Philadelphia, W. B. Saunders.

Keys, A. and Brozek, J. 1953, Body fat in adult man. Physiol. Reviews 33: 245.

Miller, R. H. and Remenchick, A. P. 1963, Problems involved in accurately measuring the $\mathrm{K}$ content of the human body. Annals of N.Y. Academy of Science, 110: 175.

Parnell, R. W. 1958, Behaviour and physique London, Edward Arnold.

Passmore, R. S. and Robson, J. S. 1971, A companion to medical studies, Oxford, Blackwell.

Pierson, W. R. 1963, A photogrammetric technique for the estimation of surface area and volume. Annals of N.Y. Academy of Science, 110: 109.

Root, W. S. and Allan, T. H. 1960, Methods in medical research, 8: 80-89.

Sheldon, W. H. 1940, The varieties of human physique, New York, Harper Bros.

Sheldon, W. H. 1954, Atlas of man, New York, Harper Bros.

Sloan, A., Burt, J. and Blythe, C. S. 1962, Estimation of body fat in younger women. J.Applied Physiol. $17: 967$.

Stouffer, J. R. 1963, Relationship of ultrasonic measurement and X-rays to body composition. Annals of N.Y. Academy of Science, 110: 31. 
Stouffer, J. R., Wallentine, M. V. and Wellington, G. H. 1959, Ultrasonic measurement of fat thickness and loin eye or live cattle and hogs. J.Animal Science, 18: 1423.

Weiner, J. S. and Lourie, J. A. 1969, Human Biology - a guide to field methods. Oxford, Blackwell.

Wilmore, J. H., Girandola, R. N. and Moody, D. L. 1971, Work on the validity of skinfold tests. J.Applied Physiol., 29: 313.

Wilmore, J. H. and Behnke, A. R. 1969, An anthropometric estimation of body density and lean body weight in young men. J.Applied Physiol. 27: 25.

Van Dobelin, K. 1961, Fat free body weight of Swedish air force pilots, Aerospace Medicine, 32: 67. 